\title{
A decade of recordkeeping education at Curtin University of Technology: Flux and flexibility
}

\section{Margaret Pember}

\author{
Curtin University of Technology
}

\begin{abstract}
Curtin University has been offering first qualifying courses in the discipline of recordkeeping for over a decade. The undergraduate degree, the Bachelor of Applied Science (Records Management), began in 1990 and the first intake of students completed their studies in November 1992. The graduate programme began as two separate graduate diplomas in records management and archives in 1994. These were amalgamated into a single qualification, the Graduate Diploma in Records Management and Archives, in 1995.

This study reports on the findings of a survey of graduates from both courses, for the years 19922000. The findings indicate that the typical graduate across both courses is likely to be female (68\%), have little prior experience in the field (56.4\%), and be aged between 21-30 years (30.9\%). She will prefer full-time (58.2\%), on-campus $(58.2 \%)$ modes of study. The first position after graduation is likely to be permanent (72\%) or of a continuing contract nature (24\%), be gained through networking contacts (46.9\%) or advertisement (26.5\%). Starting salary is likely to be in the $\$ 30,000-40,000$ range (49\%) and current salary in the $\$ 40,000-50,000$ range (34.7\%) or $\$ 50,000+$ range (28.6\%). The major difference between graduates is that those from the undergraduate degree are far more likely to have prior experience in the field and are completing the degree in order to upgrade knowledge and skills and enhance career prospects, whereas the graduate diploma students are more usually doing the course in order to facilitate a career change or re-entry to the workforce. ${ }^{\mathrm{i}}$ With only one graduate unemployed and seeking work (an undergraduate), the employment rate is $98 \%$.
\end{abstract}

\section{Expanding the career horizon}

Dick Harrington, President and Chief Executive Officer of the Thomson Corporation, a leading global e-information and solutions company, stated in his keynote speech at a recent leadership forum for senior business information leaders from Europe, North America and the Asia-Pacific, that 'we need to get the right information to the right people at the right time with the right applications software, to enable clients to make the right decisions'. ${ }^{1}$ Throughout his presentation Harrington emphasised that if corporations did not appreciate the value of information, and the timeliness with which it needed to be disseminated throughout the organisation, they would be unlikely to survive in the knowledge economy. He also stressed that pro-active management of the information/intellectual asset of the organisation is crucial to competitive advantage and corporate success, even survival, and should be a basic component of corporate strategic planning.

Jim Shepherd ${ }^{2}$ used very similar words at a Records Management Association of Australia conference back in the 80s: '.. the right information, in the right order, at the right place, in the hands of the correct people, at the lowest possible cost...' Shepherd had started expressing similar sentiments in the 70s when a group from the Brisbane City Council realised the importance of setting goals and objectives for records management and information management in the organisational context. Jim Shepherd and his team used this mantra across all levels of records management training from the Town Clerk down to junior officers of the Council and subsequently in many conference and seminar presentations across Australia. Those in education

\footnotetext{
${ }^{\mathrm{i}}$ Comments extracted from open-ended questions in the survey instrument.
} 
and training have long been teaching students of records and information management at all levels in Tafe and University of the importance of this targeted delivery of information and the need for fundamental records management standards, policies, procedures and processes behind successful management and delivery. Basic aims for records management in the policy documentation of many organisations still often focus on this concept developed by Jim Shepherd so long ago.

Managing information as an asset is not new either! Back in the 1980s Burk, Horton, and Marchand, among others, ${ }^{3}$ did a lot a work in the area of information resource management. They emphasised the need for information to play a strategic, not simply a support role, in the organisation, and for this to become possible organisational information resources needed to be carefully mapped. 'The discovery process will illuminate problems and opportunities related to current information management practices and policies. For example it will indicate your relative strengths and weaknesses with respect to information quality, accessibility, performance, use and effectiveness; highlight real dollar costs and waste .... and provide a comprehensive overview of its [the organisation's] information sources, services and systems' ${ }^{4}$ The current 'hype' about knowledge management is in part a case of changing terminology and 'discovery' by a new generation of information professionals, who have embraced the concept with skill and enthusiasm and carried it forward into another arena. Today we talk of mobilising knowledge, the value of intellectual assets, information capital, 'communities of practice', etc. with a focus on harvesting the tacit or implicit knowledge of the organisation and adding it to explicit organisational knowledge. A far greater focus on sharing and exchange of information is evident across successful organisations. Whether this process is referred to as information resource management or knowledge management, the process still needs to be grounded on basic principles for the 'best practice' management of recorded information such as those espoused in AS $4390^{5}$ and ISO $15489^{6}$. Logical progression integrates these basics into the bigger picture of organisational culture and structure with carefully formulated strategic objectives, the identified needs of client groups, the need to manage effectively the information assets and intellectual capital in a dynamic but specific, often global, environment and juridical context. The challenge is great, not one for the feint-hearted, but certainly an opportunity for pro-active information professionals. $^{7}$

Recordkeeping professionals need to consider how much longer the traditional role of records manager is likely to exist. In many organisations the role has already disappeared! In the quest for knowledge management, many organisations bypass the records section and opportunities are grasped by library or information technology staff. In still others, records personnel are grabbing the opportunities offered with both hands and moving into new and exciting, often challenging and confronting spheres of information management. Often these opportunities are disguised under new job titles such as knowledge manager or chief knowledge officer, and frequently these are new positions in the organisation with salaries several levels above the current senior records management or library positions. When position descriptions are examined, however, they may reflect the role many records managers or special librarians already perform. Opportunities are emerging and practitioners need to continue to develop professionally in order to make the most of these opportunities. To stand still is a sure road to marginalisation.

\section{Core skills and competencies}

What are the core skills and competencies required of today's and tomorrow's record, information and knowledge managers? What is the profile of the 'ideal' professional? A list of essential criteria extracted largely from job advertisements in The West Australian (1996-2000), duty statements from Western Australian Public Service position descriptions, and the recordkeeping competency standards ${ }^{8}$, includes: 
- skills, knowledge and experience in all aspects of recordkeeping as required to implement the recordkeeping standards $A S 4390^{9}$ and ISO 15489 in a variety of organisational and industry environments;

- $\quad$ high competence levels as outlined in Recordkeeping competency standards; ${ }^{10}$

- good understanding of and technical competence with information management software and systems and general Microsoft Office products and the Internet;

- general management and staff/interpersonal management skills;

- ability to perform well as a member of a team and team and project management skills and experience;

- strong written and oral communication skills;

- $\quad$ well developed analytical and problem solving skills;

- creativity and flexibility;

- professional image and manner;

- pleasant outgoing personality and confident manner;

- commitment to customer service;

It appears from the job advertisements and position descriptions surveyed that these skills and competencies should be supported by at least 2-3 years relevant experience, a basic 'apprenticeship' at the coalface.

\section{Curtin University case study}

Tertiary institutions aim to build these core skills and the underlying knowledge base into their curricula. Just how well Curtin University does this will be investigated in a subsequent phase of the study. The initial phase of the study focussed on the students, their mode of study and career progression since graduation.

The undergraduate degree, the Bachelor of Applied Science (Records Management), began in 1990 and the first intake of students completed their studies in November 1992.

The graduate programme began as two separate graduate diplomas in records management and archives in 1994. These were amalgamated into a single qualification, the Graduate Diploma in Records Management and Archives, in 1995.

Since that time there has been a steady stream of graduates from both courses. The courses themselves have changed considerably over time. Initially the undergraduate course had a common first year with library students. This was gradually reduced to common classes for the more generic information units and a greater emphasis on information technology, with students being required to do at least a 4-unit minor (and preferably an 8-unit major) in information systems.

Further course changes have recently been introduced which will produce graduates able to work across the library, records and archives fields. At the graduate level the course is moving to a modular approach, whereby students can gain a 4-unit core module in information management (certificate), then add another 4-unit module in a specific area (qualification becomes a graduate diploma), and a further 4-unit module to complete a masters degree (by coursework). These modules or clusters can be in the areas of records management, archives, knowledge management, electronic document management, Internet studies, library studies, and so on. Practitioners can build on existing qualifications. For example, someone with a graduate diploma 
can simply complete another 4-unit module or cluster to upgrade his or her qualifications to a masters degree by coursework. The traditional research masters still exists for those interested in in-depth research, while the new coursework masters provides the opportunity to upskill in areas of professional need.

All courses can be undertaken either full-time or part-time, and are offered by either internal or external (distance education and/or on-line) study.

\section{The survey}

Genoni, Exon, and Farrelly conducted a composite survey of Curtin University library and recordkeeping graduates in March 1999. Of the 157 completed questionnaires returned only 19 were from recordkeeping graduates. ${ }^{11}$ To investigate the experiences of the recordkeeping graduates specifically, a questionnaire was developed and distributed to 91 Curtin graduates in April/May 2001 (40 to undergraduates and 51 to graduate diploma graduates). Four were returned to Curtin marked 'returned to sender, not at this address' and these have not been included in the calculations. Considerable effort was made to contact graduates before the mailout to check current addresses. All students graduating in recordkeeping courses were targeted, even those graduating the previous semester. 55 questionnaires had been completed and returned by 1 September, a 63\% return rate. The results below are based on an analysis of these 55 returned questionnaires.

In order to encourage recipients to be as candid as possible the respondents were not required to identify themselves and questionnaires were not numbered or marked in any way. However, provision was made for the supply of contact details, should the respondents be willing and available for further in-depth research. $69 \%$ of respondents supplied their contact details (38 out of 55). It is intended that these graduates form the nucleus of a focus group in a further phase of the research.

\section{Survey results}

The questionnaire was divided into 4 sections. The first section was to determine the nature of the course studied, the second the characteristics of the student cohort, the third their reasons for embarking on a study programme in records/archives, and lastly a section on employment history since graduation.

\section{Course}

$\begin{array}{rl}\text { Frequency } & \text { \% } \\ 22 & 40 \\ 33 & 60 \\ 55 & 100\end{array}$

$\begin{array}{lll}\text { Bachelor of Applied Science (Records Management) } & 22 & 40 \\ \text { Graduate Diploma in Records Management and Archives } & 33 & 60 \\ \text { Total } & 55 & 100\end{array}$

Table 1: Recordkeeping course completed by respondents, 1992-2000

The response to this question reflects the general enrolment pattern of students in the undergraduate (43.9\%) and graduate diploma (56.1\%) courses over the period the courses have been available. 


\section{Mode of study}

Bachelor of Applied Science (Records Management)

$\begin{array}{cc}\text { Frequency } & \% \\ 15 & 68.2 \\ 4 & 18.2 \\ 3 & 13.6 \\ 22 & 100\end{array}$

Graduate Diploma in Records Management and Archives

$\begin{array}{lll}\text { Full-time } & 17 & 51.5 \\ \text { Part-time } & 12 & 36.4 \\ \text { Combination } & 4 & 12.1 \\ \text { Total } & 33 & 100\end{array}$

Table 2: Full-time/part-time choices of recordkeeping graduates, 1992-2000

At both undergraduate and graduate level full-time study is the preferred option of respondents; with $68.2 \%$ of undergraduate students and $51.5 \%$ of graduate students making this choice. When averaged across courses this full-time choice is made by $58.2 \%$ of students.

$\begin{array}{ccc}\text { Bachelor of Applied Science (Records Management) } & \text { Frequency } & \% \\ \text { Internal } & 12 & 54.5 \\ \text { External } & 7 & 31.9 \\ \text { Combination } & 3 & 13.6 \\ \text { Total } & 22 & 100\end{array}$

Graduate Diploma in Records Management and Archives

$\begin{array}{lll}\text { Internal } & 20 & 60.6 \\ \text { External } & 9 & 27.3 \\ \text { Combination } & 4 & 12.1 \\ \text { Total } & 33 & 100\end{array}$

Table 3 Internal/external choices of recordkeeping graduates, 1992-2000

The internal mode of study is the preferred study option, especially at the graduate diploma level, with almost 2/3 (60.6\%) of completing students making this choice. The average for completing students across both courses is $58.2 \%$ internal, $29.1 \%$ external and $12.7 \%$ of students combining internal and external modes to suit their particular needs.

\section{Gender}

Bachelor of Applied Science (Records Management) Frequency $\%$

Male $13 \quad 32.5$

Female

$27 \quad 67.5$

Total number of graduates

$40 \quad 100$ 
Graduate Diploma in Records Management and Archives

$\begin{array}{lll}\text { Male } & 16 & 31.5 \\ \text { Female } & 35 & 68.5 \\ \text { Total number of graduates } & 51 & 100\end{array}$

Table 4: Gender of recordkeeping graduates, 1992-2000

Overall there is very little difference in the gender balance between graduates of the undergraduate and graduate diploma courses; the ratio being approximately 1/3 (32\%) male to $2 / 3$ female (68\%) across both courses. These figures represent all students completing the courses, not just those returning the questionnaire.

\section{Age}

$\begin{array}{ccc}\text { Bachelor of Applied Science (Records Management) } & \text { Frequency } & \% \\ <=21 & 3 & 13.6 \\ 21-30 & 4 & 18.2 \\ 31-40 & 10 & 45.5 \\ 41-50 & 4 & 18.2 \\ 51-60 & 1 & 4.5 \\ >=60 & 0 & 0 \\ \text { Total } & 22 & 100 \%\end{array}$

Graduate Diploma in Records Management and Archives

$\begin{array}{lll}<=21 & 0 & 0 \\ 21-30 & 13 & 39.4 \\ 31-40 & 6 & 18.2 \\ 41-50 & 12 & 36.4 \\ 51-60 & 2 & 6 \\ >=60 & 0 & 0 \\ \text { Total } & 33 & 100 \%\end{array}$

Table 5: Age of respondents enrolling in recordkeeping courses, 1992-2000

Maturity of students is reflected in the age table. Ages were gauged at the commencement of the study programme. At the undergraduate level only three respondents (13.6\%) commenced the degree before they were 21 . The highest percentage commenced study in their 30s (45.5\%), followed by those in their 20s and 40s (both 18.2\%). At the graduate diploma level $39.4 \%$ of completing students began their course of study in their 20s, followed by $36.4 \%$ in their 40s, and $18.2 \%$ in their 30s. When undergraduate figures are combined with graduate diploma figures the spread becomes more even with $30.9 \%$ of students commencing study in their 20 s, $29.1 \%$ in their 30s and 29.1\% in their 40s. Only 5.5\% begin study in their 50s, and 5.5\% under 21. 


\section{Prior experience}

Bachelor of Applied Science (Records Management)

$$
\text { Yes }
$$

No

Total

$\begin{array}{cc}\text { Frequency } & \% \\ 13 & 59.1 \\ 9 & 40.9 \\ 22 & 100\end{array}$

Graduate Diploma in Records Management and Archives

$\begin{array}{lll}\text { Yes } & 11 & 33.3 \\ \text { No } & 22 & 66.7 \\ \text { Total } & 33 & 100\end{array}$

Table 6: Prior experience of recordkeeping graduates before commencement of study

Quite a significant difference in recordkeeping experience prior to commencement of study is apparent between courses. 59.1\% of undergraduate students have prior experience in the field; whereas this is the case for only $33.3 \%$ of graduate students. The average across courses is $43.6 \%$ with prior experience and $56.4 \%$ without. The nature of this experience covers the whole gamut of recordkeeping practice in the public and private sector from correspondence control and file management to appraisal and disposal. The amount of this experience is evenly spread from those with less than two years experience to those with more than 15 years experience.

\section{Employment history}

Bachelor of Applied Science (Records Management)

$\begin{array}{cl}\text { Frequency } & \% \\ 14 & 63.6 \\ 4 & 18.2 \\ 3 & 13.7 \\ 1 & 4.5 \\ 0 & 0 \\ 22 & 100\end{array}$

Continuous/full-time permanent

Almost continuous casual/contract

Initial problems, now continuous

Unemployed, seeking work

Unemployed, not currently available

22

100

Graduate Diploma in Records Management and Archives

Continuous/full-time permanent

Almost continuous casual/contract

Initial problems, now continuous

Short-term casual, periods unemployment

Unemployed, seeking work

Unemployed, not currently available

Total
$18 \quad 64.3$

$8 \quad 28.5$

13.6

13.6

$0 \quad 0$

$5 \quad *^{\mathrm{ii}}$

$33 \quad 100$

Table 7: Employment history of recordkeeping graduates, 1992-2000

\footnotetext{
ii *Three graduates are currently on maternity leave so have not been included in the figures. Two were in full-time employment until they took extended maternity leave; the other took leave immediately after graduation. Two other graduates have not yet sought employment in the field.
} 
The employment pattern across both courses is quite similar. When figures are combined across courses the majority of graduates (96\%) has been in continuous or almost continuous employment since graduation (24\% of these are in contract or casual employment of a continuing nature). Four graduates noted initial problems on graduation but are now in permanent employment. Only one graduate is reported as 'unemployed, seeking work' (2\%) and one reported 'long periods of unemployment (2\%). It should be noted that these figures include a number of students who graduated at the end of 2000, a matter of months after the survey was distributed, and all were recorded as employed. It appears that getting that first job is not a major problem, although it may initially be of a contract nature rather than a permanent position.

\section{Annual salary level of first recordkeeping position after graduation}

Bachelor of Applied Science (Records Management)

$\begin{array}{cl}\text { Frequency } & \% \\ 6 & 28.6 \\ 10 & 47.7 \\ 4 & 19 \\ 1 & 4.7 \\ 1 & 0 \\ 22 & 100\end{array}$

Graduate Diploma in Records Management and Archives

$\begin{array}{lll}\$ 20,000-30,000 & 14 & 46.6 \\ \$ 30,000-40,000 & 15 & 50 \\ \$ 40,000-50,000 & 1 & 3.4 \\ \$ 50,000+ & 0 & 0 \\ \text { N/A (2 working in another field, 1 maternity leave) } & 3 & 0 \\ \text { Total } & 33 & 100\end{array}$

Table 8: Annual salary level of first recordkeeping position

The first records position after graduation for almost half (49\%) of the graduates of either course is in the $\$ 30,00-40,000$ range. $39.3 \%$ begin in the $\$ 20,00-30,000$ range, $9.8 \%$ in the $\$ 40,000$ 50,000 range, and $1.9 \%$ over $\$ 50,000$. Less undergraduate than graduate diploma level students start in the \$20,000-30,000 range; this may be a result of the higher percentage with prior experience at the undergraduate level and needs further investigation to prove or disprove.

\section{Current annual recordkeeping salary level}

$\begin{array}{lcl}\text { Bachelor of Applied Science (Records Management) } & \text { Frequency } & \% \\ \$ 20,000-30,000 & 2 & 9.5 \\ \$ 30,000-40,000 & 4 & 19 \\ \$ 40,000-50,000 & 6 & 28.6 \\ \$ 50,000+ & 9 & 42.9 \\ \text { N/A (unemployed, seeking work) } & 1 & 0 \\ \text { Total } & 22 & 100\end{array}$


Graduate Diploma in Records Management and Archives

$\begin{array}{lll}\$ 20,000-30,000 & 3 & 10.7 \\ \$ 30,000-40,000 & 9 & 32.1 \\ \$ 40,000-50,000 & 11 & 39.3 \\ \$ 50,000+ & 5 & 17.9 \\ \text { N/A (not currently available) } & 5 & 0 \\ \text { Total } & 33 & 100\end{array}$

Table 9: Current annual salary levels of recordkeeping graduates

Given that the figures include graduates from 1992-2000, the levels are purely indicative. For example, three graduate diploma students employed in the \$20,000-30,000 range only graduated at the end of 2000 so it is their starting salary as well as their current salary. Further work will cross-tabulate years of experience with salary level. Three graduates are currently on maternity leave so have not been included in the figures. Two were in full-time employment $(\$ 40,000$ 50,000 level) until they took extended maternity leave; the other has yet to obtain her first employment in the field. Two other graduates have not yet applied for employment in the field. Overall figures indicate that $10.2 \%$ of graduates are employed in the $\$ 20-30,000$ range, $26.5 \%$ in the $\$ 30-40,000$ range, $34.7 \%$ in the $\$ 40-50,000$ range, and $28.6 \%$ over $\$ 50,000$.

\section{Method of gaining first recordkeeping position}

$\begin{array}{lll}\text { Bachelor of Applied Science (Records Management) } & \text { Frequency } & \text { \% } \\ \text { Advertisement newspaper/public service notice } & 7 & 33.3 \\ \text { Networking } & 7 & 33.3 \\ \text { Employment agency } & 2 & 9.5 \\ \text { Remained with same employer } & 5 & 23.9 \\ \text { N/A (unemployed, seeking work) } & 1 & 0 * \text { iii } \\ \text { Total } & 22 & 100\end{array}$

Graduate Diploma in Records Management and Archives

$\begin{array}{lll}\text { Advertisement newspaper/public service notice } & 6 & 21.4 \\ \text { Networking } & 16 & 57.1 \\ \text { Employment agency } & 4 & 14.3 \\ \text { Remained with same employer } & 2 & 7.2 \\ \text { N/A (unemployed, seeking work) } & 0 & 0^{*} \\ \text { N/A (not currently available) } & 5 & 0^{*} \\ \text { Total } & 33 & 100\end{array}$

Table 10: Method of gaining first recordkeeping position, graduates 1992-2000

\footnotetext{
iii *Again those not in employment for various reasons such as maternity leave have not been included in the calculations.
} 
At the undergraduate level a third of graduates obtained their first recordkeeping position through advertisement (only one through public service notices). Networking contacts accounted for another third of first appointments; and a further 23.9\% remained with the same employer. 9.5\% gained employment through a specialist information related employment agency. At the graduate diploma level over half (57.1\%) cited networking of some kind as the catalyst for employment (particularly networking with professional association (RMAA and ASA) contacts, personal contacts and university staff.) Advertisements accounted for $21.4 \%$ of first appointments, employment through agencies $14.3 \%$, and those remaining with the same employers accounted for $7.2 \%$. When figures are combined for undergraduate and graduate diploma courses the predominant mode of employment is networking at $46.9 \%$, followed by advertisement at 26.5\%. 14.3\% remained with the same employer probably indicating some level of support on the part of the employer. Employment agencies play a significant role at $12.3 \%$.

\section{Profiles of graduates}

From the data collected the typical graduate of the undergraduate course is likely to be female (67.5\%), have prior experience in the field (59.1\%), and be aged between 31-40 years at the commencement of the course (45.5\%). She will prefer full-time (68.2\%), on-campus (54.5\%) modes of study. The first position after graduation is likely to be permanent $(77.3 \%)$, or of a continuing contract nature (18.2\%). First recordkeeping positions are usually gained through a newspaper advertisement (33.3\%) or networking contacts (33.3\%), although a significant number remain with the same employer $(23.9 \%)$. Starting salary is likely to be in the $\$ 30,000$ 40,000 range (47.7\%) and current salary in the \$50,000+ range (42.9\%). ${ }^{\text {iv }}$

The typical graduate of the graduate diploma course is likely to be female (68.5\%), have no prior experience $(66.7 \%)$, and be aged between $21-30$ years $(39.4 \%)$ or $41-50$ years $(36.4 \%)$ at commencement of study. She will prefer full-time (51.5\%), on-campus (60.6\%) modes of study. The first position after graduation is likely to be permanent $(67.9 \%)$ or of a continuing contract nature (28.5\%), and be gained through networking contacts (57.1\%). Starting salary is likely to be in the $\$ 30,000-40,000$ range (50\%) and current salary in the $\$ 40,000-50,000$ range (39.3\%).

The typical graduate across both courses is likely to be female (68\%), have little prior experience in the field (56.4\%), and be aged between 21-30 years (30.9\%). She will prefer full-time (58.2\%), on-campus (58.2\%) modes of study. The first position after graduation is likely to be permanent $(72 \%)$ or of a continuing contract nature $(24 \%)$, be gained through networking contacts (46.9\%) or advertisement (26.5\%). Starting salary is likely to be in the $\$ 30,000-40,000$ range (49\%) and current salary in the $\$ 40,000-50,000$ range (34.7\%) or $\$ 50,000+$ range (28.6\%). The major difference between graduates is that those from the undergraduate degree are far more likely to have prior experience in the field and are completing the degree in order to upgrade knowledge and skills and enhance career prospects, whereas the graduate diploma students are more usually doing the course in order to facilitate a career change or re-entry to the workforce after childraising is complete. ${ }^{\mathrm{v}}$ With only one graduate unemployed and seeking work (an undergraduate), the employment rate is $98 \%$ (students unavailable for employment, for example those on maternity leave, are not included in these figures).

\footnotetext{
${ }^{\text {iv }}$ Further work will cross-tabulate salary scales to years of experience since graduation.

${ }^{v}$ Comments extracted from open-ended questions in the survey instrument.
} 


\section{Graduate comments}

Graduates were given the opportunity to comment on various aspects of the course and the educational experience. Open-ended responses to positive aspects of the course include comments such as 'a good balance between technical and theoretical', 'high degree of professionalism and enthusiasm amongst staff', 'information systems units', 'practica', 'case studies', 'site visits', 'workplace projects', 'group work', 'development of mentoring relationships', and 'comprehensive feedback and support'.

Positive outcomes reported include 'development of personal and professional confidence', 'feelings of self-fulfilment', 'empowerment', 'development of networking contacts', 'formal recognition of the skills acquired through practical experience', 'professional recognition', 'employment at managerial level', 'knowledge of the higher level strategic requirements and ramifications of records management', 'continuous employment and good career prospects'.

Suggestions for improving the course include comments such as 'less focus on library studies', 'replacement of some of the library units with more records and archives units', 'closer connection to the workplace for some lecturers', 'greater use of tutors still in the workplace', 'stronger management focus', 'even greater focus on technology', 'more hands-on work experience', and 'improved access to some lecturers'. A number of graduates of the graduate diploma courses also noted that it would almost impossible to include anything extra in the course given the time constraints of the one-year course. Despite these suggestions for improvement, the majority of students was very positive about the nature of the course and the outcomes, particularly in the area of employment prospects and was very pleased they had completed the course (96\%).

Both positive and negative aspects of the feedback have implications for educators and will need to be investigated more fully through focus groups and a thorough mapping of course content to identified competencies and standards and the perceived needs and direction of the industry.

\section{Further research}

Alison Jago, ${ }^{12}$ writing back in 1993 about the situation in the United Kingdom, bemoaned the dearth of suitable applicants when recruiting information staff. Jago noted that despite job losses due to company streamlining, the so called 'leaner meaner' approach, good staff were extremely difficult to find. She also noted that most job seekers in the field were already in work and wanted to change for positive reasons. To be tempting, the job offered had to satisfy some identified professional need, such as offering broader experience or additional skills. Job satisfaction and personal development were more important than higher salaries as prime motivators for job change. This type of applicant was generally 'prepared to wait until the right job came along’ (1993: 31). Those applicants seeking job changes for negative reasons were more likely to accept positions offered as an escape mechanism from their current employment.

Has anything changed since Jago did this study? Is it any different in Australia? The cry is often heard, 'we just can't get the staff we need to fill the job vacancies we have' or that when positions are advertised suitable applicants are not available and they have to be re-advertised or 'less than optimum' appointments made. These comments are based on purely anecdotal evidence and will need to be investigated fully in a future phase of the study.

\section{Conclusion}

The nature of our work has changed forever in this exciting, dynamic, highly technical, more litigious, more competitive global environment. For many organisations this has meant the loss 
of the traditional records manager, even the whole records section, as we knew it. Few would deny that the profession has moved from one based largely on a passive centralised reception of paper-based documents to one that abounds with exciting, albeit challenging, possibilities in a constantly evolving distributed electronic world. Emphasis has moved from the purely reactive management of hard-copy records to encompass the pro-active management of the electronic record, and for many, a far more active role in the provision of information services to one's client group. Theoretical and industry driven developments mean that education and training for recordkeeping professionals need to encompass a wider range of knowledge and skills than ever before. New roles will demand new and constantly updated knowledge and skills. Unless recordkeeping practitioners continue to develop professionally to meet the demands of these new roles they risk losing leadership roles to other information professionals. It is estimated that it now takes only five years for current skill levels to become obsolete, so commitment to continuing professional development becomes critical, and something for which individuals should take personal responsibility. ${ }^{13}$

Given the increasingly evident emphasis on standards, and information and communications technology, graduates need to demonstrate 'hands-on' competence in a wide range of practical and technical skills in these areas to complement their understanding of the basic principles underlying information management theory. On top of these theoretical understandings and technical competencies, sought after graduates exhibit a wide range of transferable workplace skills such as interpersonal or people skills, broad communication skills, self and team management skills, and intellectual skills. Ideally one needs to 'do time' at the coalface, basically an apprenticeship, where the theory learned can be put into practice. Some graduates (59.1\% at the undergraduate level) did this 'time' before they started study, others do it while they study, and still others do it after their study is complete. This 'hands-on' experience appears to give a high level of confidence as well as honing the practical and technical skills required in the workplace. Those who have theoretical knowledge backed with experience also seem to have greater credibility amongst peers and prospective employers. ${ }^{14}$ The consolidation of these fundamental recordkeeping skills through this basic 'apprenticeship' provides a good foundation on which to build the next level of skills required for a successful career, those of management and some practitioners then make the decision to develop these skills through further study in the management area.

It is encouraging to note that students graduating from Curtin University recordkeeping courses are finding ready employment in the field, with $98 \%$ of respondents employed at the time of the study. Students were very open about their experiences and perceptions of the courses, and many made constructive suggestions for change. The overall satisfaction level of $96 \%$ reflects a perceived correlation by the graduates between knowledge and skills acquired in the course and those required in the workplace. Curtin courses in recordkeeping and all aspects of information and library studies have changed considerably over the past decade and will continue to change to meet the needs of the profession and provide well-rounded programmes for aspiring information professionals.

\footnotetext{
${ }^{1}$ Harrington, D. (2001). $11^{\text {th }}$ European Business Information Conference (EBIC) in Rome, March 2001. Reported in TFPL Newsletter Spring 2001, p.1.

${ }^{2}$ Shepherd, J. (June 2001). Personal communication.

${ }^{3}$ Burk, C. \& Horton, F. W. (1988). Information resource management: A complete guide to discovering corporate information resources. Prentice Hall; Horton, F.W. (1979). Information resources management: Concepts and cases. Cleveland, OH: Association for Systems Management; Marchand, D.M. \& Horton, F.W. (1986). Infotrends: Profiting from your information resources. New York: Wiley, etc.

${ }^{4}$ Burk, C. \& Horton, F. W. (1988). Information resource management: A complete guide to discovering corporate information resources. Prentice Hall, pp. 4-5.

${ }^{5}$ Standards Australia. (1996). Records management AS4390-1996. Homebush, NSW: SA.

${ }^{6}$ International Standards Organization. (2001). ISO 15489 Information and documentation — Records management, (Parts 1 \& 2), the international records management standard launched at Montreal in October 2001.
} 


\footnotetext{
${ }^{7}$ See the work of Southon, G., \& Todd, R. (2001). Library and information professionals and knowledge management: Conceptions, challenges and conflicts. Australian Library Journal, 50(2); Todd, R.J., \& Southon, G. (2001). Educating for a knowledge management future; Perceptions of library and information professionals. Australian Library Journal, 50(4); Abell, A., \& Oxbrow, N. (2001). Competing with knowledge: The information profession in the knowledge management age. London: Library Association; Milne, P. (2000). Information professionals and the knowledge-aware, intelligent organisation: Skills for the future. Australian Library Journal, 49(2): 139-150.

${ }^{8}$ Taken from Western Australian Public Service job descriptions and job advertisements in The West Australian over a 5-year period (1996-2000), and recordkeeping competency standards.

${ }^{9}$ Standards Australia. (1996). Records management AS4390-1996. Homebush, NSW: SA.

${ }^{10}$ Business Services Training Australia Ltd. (2000). Recordkeeping competency standards draft 3 October 2000: Training package. ANTA; and original version Archives and records competency standards, November 1997. Another useful tool is the Competency profile: Information resources management specialists in archives, libraries and records management: A comprehensive cross-sectoral competency analysis. The Alliance of Libraries, Archives and Records Management (ALARM) in partnership with the Cultural Human Resources Council with the support of Human Resources Development Canada in April 1999 published this profile.

${ }^{11}$ Genoni, P., Exon, M. \& Farrelly, K. (2000). Graduate employment outcomes for qualifying library and records management courses at Curtin University of Technology. Australian Library Journal, 49(3): 245-258.

${ }^{12}$ Jago, A. (1993). Join the team! Recruiting for information professionals. Library Management, 14(1): 31-34.

${ }^{13}$ Pember, M. (1998). The rise of the 'new age' records management professional: Records management education and training in Australia. Records Management Journal, 8(3): 63-76.

${ }^{14}$ Comments based on anecdotal evidence. This is another thread that will be followed in subsequent research.
} 